\title{
Hydrothermal base catalysed treatment of Kraft lignin - time dependent analysis and a techno-economic evaluation for carbon fibre applications
}

\author{
Malte Otromke ${ }^{\mathrm{a}, \mathrm{b}, 1}$, Peter S. Shuttleworth ${ }^{\mathrm{c}}$, Jörg Sauer ${ }^{\mathrm{a}}$, Robin J. White ${ }^{\mathrm{b}, *}$ \\ ${ }^{a}$ Institute of Catalysis Research and Technology (IKFT), Karlsruhe Institute of Technology (KIT), Eggenstein-Leopoldshafen, Germany \\ ${ }^{\mathrm{b}}$ Sustainable Catalytic Materials Group, Division Hydrogen Technologies, Fraunhofer Institute for Solar Energy Systems ISE, Heidenhofstr. 2, 79110 Freiburg, Germany \\ ${ }^{c}$ Institute of Polymer Science and Technology, Spanish National Research Council (ICTP-CSIC), Madrid, Spain
}

\author{
Keywords: \\ Kraft lignin \\ Hydrothermal treatment \\ Base catalysed depolymerization \\ Techno-economic analysis \\ Bio-aromatics
}

\begin{abstract}
A B S T R A C T
The hydrothermal base-catalysed treatment of industrial Kraft lignin (KL) is investigated as a basis for production of a sustainable carbon fibre precursor, with a focus on the time-dependent evolution and impact on precursor properties. Hydrothermal treatment was performed at $T=300^{\circ} \mathrm{C}$ and $p=180 \mathrm{bar}$, with the retention time $\left(\mathrm{t}_{\mathrm{ret}}\right)$ varied between $8,12,16,20$, and 24 mins. Molecular weight distribution and thermal stability of the processed lignin were close to maximum after $8 \mathrm{~min}$, and $12-16 \mathrm{~min}$ respectively. Chemical modification was found to continue (e.g. demethoxylation) over the entire $t_{\text {ret }}$ range $(24 \mathrm{~min})$. Analysis of the recovered oily phase indicated catechol derivatives were stable end-products with, e.g., vanillin and guaiacol as intermediates. A techno-economic analysis indicated a price of ca. $1600 € / \mathrm{t}$ at a production capacity of $10 \mathrm{kt} / \mathrm{a}$ is achievable, with main cost-drivers being lignin (60\%), fixed costs (20\%), and energy (10\%).
\end{abstract}

\section{Introduction}

With increasing interest in the production of sustainable aromatic chemicals and materials from lignin, there is an associated need for efficient process development. In this context, $\mathrm{CO}_{2}$ can be used in lignin precipitation from processes including LignoBoost ${ }^{\circledR}$, LignoForce ${ }^{\mathrm{TM}}$, and SLRP $^{\oplus}$ - with the integration of these routes into existing Kraft mills, it is expected that low-cost Kraft lignin (KL) will become more available as feedstock in the coming years (Kouisni et al., 2012; Lake and Blackburn, 2014; Tomani, 2010). Whilst there is an interest in KL as a platform to produce renewable aromatics (e.g. as an alternative to existing BTX production, (Gargulak et al., 2000)), it is typically employed as fuel in existing Kraft mill recovery boilers (Ragnar et al. 1999-2014; Tran and Vakkilainnen, 2007). It is anticipated that pulp generated via the Kraft process will be available at a scale of $\geq 100 \mathrm{Mt}$. towards the end of the decade, (FAO - Food and Agriculture Organization of the United Nations, 2015) corresponding to a supply in excess of $30 \mathrm{Mt}$./a of KL (Björk et al., 2015; Gellerstedt et al., 2013).

Chemically, this KL has a reduced $\beta-O-4$ bond content (ca. 80-90\% relative to the parent lignin), and a concurrent three-fold increase in phenolic-OH group content (Alekhina et al., 2015a; Alekhina et al., 2015b; Gierer, 1980; Nagy et al., 2010; Rinaldi et al., 2016). The characterisation of $\mathrm{KL}$ is therefore necessary to determine further processing dynamics. In this context there has been renewed interest in $\mathrm{KL}$ as a precursor for carbon fibre (CF) production (Baker and Rials, 2013). Previous investigations demonstrate tensile strengths of CFs produced from KL (ca. $0.5 \mathrm{GPa}$ ) are not high enough to compete with commercially available fibres, although this is not inhibiting further development of the technology for applications in the automotive industry as well as nonwoven fabrics for heat retardants and insulations (Paul et al., 2015). With large scale, long term adoption in mind, lignin-derived CFs must be prepared such that they possess three-fold higher tensile strengths and increased Young's moduli compared to current values, whilst also being commercial priced at $8-13 € / \mathrm{kg}$ (Baker and Rials, 2013).

The aromatic backbone and presence of heteroatoms in KL influences carbonisation processes, with literature indicating improved stabilisation and an increased yield (Frank et al., 2014). Concerning technology development, a number of challenges are worth highlighting; lignin has a tendency to react with itself during (melt)-spinning, whilst heterogeneity (e.g. in terms of molecular weight $\left(\mathrm{M}_{\mathrm{w}}\right)$ ) typically inhibits stable CF spinning (Baker and Rials, 2013; Kadla et al., 2002). During stabilisation/carbonisation of as-spun lignin-based $\mathrm{CFs}$, polymerisation is known to occur and is considered advantageous for stable CF structure formation (Frank et al., 2014). Conversely, if these "cross" polymerisation reactions do not proceed within the $\mathrm{CF}$ bulk matrix, evaporation can occur, which in turn reduces the overall

\footnotetext{
* Corresponding author at: The Netherlands Organisation for Applied Scientific Research (TNO), High Tech Campus 25, 5656AE Eindhoven, the Netherlands. E-mail address: robin.white666@googlemail.com (R.J. White).

${ }^{1}$ Current address: Clariant Produkte (Deutschland) GmbH, Group Process Technology, Frankfurt am Main, Germany.
} 
material yield and tensile strength (Mainka et al., 2015).

As current research and literature highlights there is a growing in interest in melt spinning as the preferred method for CF preparation (Baker et al., 2012; Kadla et al., 2002; Sudo and Shimizu, 1992) with solvent spinning considered as an alternative option. Lignin treatments which result in a more uniform $\mathrm{M}_{\mathrm{W}}$ distribution with an associated higher thermal stability would be of significant interest provided a linear molecular structure (preferably with a high $\mathrm{M}_{\mathrm{w}}$ ) is maintained. Regarding lignin processing and "deconstruction", hydrothermal base catalysed depolymerisation (HBCD) is proposed to be suitable to address the first two criteria. In $\mathrm{HBCD}, 1 \mathrm{M} \mathrm{NaOH}$ (aq) is used as a solvent, with treatment of the lignin performed at $\mathrm{T} \approx 300^{\circ} \mathrm{C}$ at a retention time $\left(\mathrm{t}_{\mathrm{ret}}\right)$ of ca. $15 \mathrm{~min}$. This is known to alter technical lignin properties in the aforementioned way (Beauchet et al., 2012; Erdocia et al., 2014; Katahira et al., 2016; Mahmood et al., 2013; Miller et al., 2002; Roberts et al., 2011; Schmiedl et al., 2012; Toledano et al., 2014). Regarding further advantages, the HBCD approach employs technologies available at existing Kraft mills equipped with one of the aforementioned lignin precipitation technologies (e.g. LignoBoost ${ }^{\circledR}$ ).

As a follow up to our recent article (Otromke et al., 2018) and with regard to our continuing efforts regarding lignin utilisation in chemical and material production (Aicher et al., 2014), this report investigates HBCD processing of KL to demonstrate the potential of the product as a feed-stock for CF production and provide additional insights into process design. In our previous report, the process was described with respect to initial screening runs and results demonstrating the suitability of a methanol-based extraction for the separation of the low and high $M_{w}$ fractions of KL. The latter was used as feed for the subsequent HBCD in $1 \mathrm{M} \mathrm{NaOH}$ (aq) at $300^{\circ} \mathrm{C}$ with $t_{\text {ret }}=16 \mathrm{~min}$. In this report, product evolution and material properties are investigated as a function of $t_{\text {ret }}$. A techno-economic evaluation of the proposed process is performed and generates information regarding minimum selling price relative to potential "Return On Investment" (ROI), and the major cost influencing factors when operating at a Kraft mill as operated with LignoBoost ${ }^{\circledR}$ technology (plant scale: $10 \mathrm{kt} / \mathrm{a}$ plant).

\section{Material and methods}

The reader is referred to our recent report for further details regarding materials and methods (Otromke et al., 2018). Additionally, in this report, HBCD kinetic analysis was performed based on five runs with different $t_{\text {ret }}$ (in random order). Numbering of the runs and analytics applied are described in Table 1 . The KL utilised is this study was provided by a Domtar pulp mill (Plymouth, North Carolina, USA) and was precipitated via the LignoBoost ${ }^{\circledR}$ process (installed at the mill in 2015).

\section{Hydrothermal base catalysed treatment}

All the investigated runs employed the high $\mathrm{M}_{\mathrm{w}}$ fraction (HMW) (i.e. after $\mathrm{MeOH}$ extraction as feed (Otromke et al., 2018). Experimental runs were performed at $T=300{ }^{\circ} \mathrm{C}$ and $p=180$ bar. Calculated yields demonstrated a decrease in the solid fraction from retention time $\left(t_{\text {ret }}\right) 8$ to $12 \mathrm{~min}$, reaching a plateau at ca. $70 \mathrm{wt} \%$ (Fig. 1(a)). Regarding the oil phase yield, ca. $5 \mathrm{wt} \%$ was calculated, resulting in ca. $20-25 \mathrm{wt} \%$ of unaccounted compounds (Table S1). The yield of the latter compounds is ca. $10-15 \mathrm{wt} \%$ higher compared to our first trial runs (Otromke et al., 2018), hinting at a shift in the reaction network, possibly caused by coke formation on the reactor walls. Since no detectable gas phase evolved during the experiments, the unaccounted compounds are proposed to be found in the $\mathrm{pH} 2$ aqueous phase (i.e. after extraction with ethyl acetate). This indicates that the reaction network has shifted towards more polar, low $\mathrm{M}_{\mathrm{w}}$ products. Regarding the obtained titration curves, as recorded for the feed and all five product solutions (Fig. 1(b)), the untreated $\mathrm{MeOH}$ insoluble fraction (HMW) clearly has a higher buffer capacity in the upper $\mathrm{pH}$ range to $\mathrm{pH} 8$. At this point, the curve combines with the other curves in a steeper slope. Reaching $\mathrm{pH} 10$ requires roughly twice the number of protons when precipitating the HMW fraction of untreated lignin compared to the precipitated solids after HBCD.

\subsection{Gel permeation chromatography}

Gel Permeation Chromatography (GPC) analysis for the runs \#K1-3 (Table 1; Table 2 and Fig. 1(c)); i.e. $t_{r e t}=8,16$, and 24 min), shows that for $\mathrm{pH} 10$ solids, already after $\mathrm{t}_{\text {ret }}=8 \mathrm{~min}$ a reduction of the molecular weight $\left(\mathrm{M}_{\mathrm{W}}\right)$ by ca. $60 \%$ can be observed reaching a maximum of $68 \%$ at $\mathrm{t}_{\mathrm{ret}}=16 \mathrm{~min}$ and decreasing to $64 \%$ for $\mathrm{t}_{\mathrm{ret}}=24 \mathrm{~min}$ suggesting repolymerisation occurs. $\mathrm{pH} 2$ solids show a comparable behaviour with $63 \%, 70 \%$, and $64 \%$ reduction. The oil phase constitutes in weight average mainly of dimers, while number average are monomers (please compare with Gas Chromatography (GC) analysis below); Section 3.4 please note for clarity, the amount of low $M_{w}$ compounds is overestimated due to the usage of pullulan as calibration standard).

\subsection{Elemental analysis}

Time-resolved elemental analysis (EA) trends are comparable for the $\mathrm{pH} 10$ and $\mathrm{pH} 2$ solids (Fig. 1(d) and Table S2). Carbon content is slightly reduced for $t_{\text {ret }}=8 \mathrm{~min}$ and then increases to ca. $70 \mathrm{wt} \%$. This increase is caused by removal of oxygenated groups. The amount of sulphur is reduced by $>60 \%$ for $t_{\text {ret }}=8 \mathrm{~min}$ and generally remains at this level throughout the experimental range (only pH 10 solids after $24 \mathrm{~min}$ are considered an outlier, with no explanation for the higher sulphur content). The solids and oil phases gave about $75-80 \%$ of the mass balance and considering the elemental composition of the remaining $20-25 \%$ hints at small organic acids, alcohols, and/or aldehydes with the majority of the sulphur (Table 3 ).

Table 1

Reactions performed for the kinetic trials with respective analytics.

\begin{tabular}{|c|c|c|c|c|c|c|c|c|c|c|}
\hline \multirow[t]{2}{*}{ Run \# } & \multirow{2}{*}{$\begin{array}{l}\text { Retention time, } \mathrm{t}_{\text {ret }} \\
{[\mathrm{min}]}\end{array}$} & \multicolumn{9}{|c|}{ Applied analytical techniques (X) } \\
\hline & & 1 & 2 & 3 & 4 & 5 & 6 & 7 & 8 & 9 \\
\hline \#K1 & 8 & $\mathrm{X}$ & $\mathrm{X}$ & $\mathrm{X}$ & $\mathrm{X}$ & $\mathrm{X}$ & $\mathrm{X}$ & $\mathrm{X}$ & $\mathrm{X}$ & $\mathrm{X}$ \\
\hline \#K4 & 12 & $\mathrm{X}$ & $\mathrm{X}$ & & $\mathrm{X}$ & $\mathrm{X}$ & & $\mathrm{x}$ & & \\
\hline \#K3 & 16 & $\mathrm{X}$ & $\mathrm{X}$ & $\mathrm{X}$ & $\mathrm{X}$ & $\mathrm{X}$ & $\mathrm{X}$ & $\mathrm{X}$ & & $\mathrm{X}$ \\
\hline \#K5 & 20 & $\mathrm{X}$ & $\mathrm{X}$ & & $\mathrm{X}$ & $\mathrm{X}$ & & $\mathrm{x}$ & & \\
\hline \#K2 & 24 & $\mathrm{X}$ & $\mathrm{X}$ & $\mathrm{X}$ & $\mathrm{X}$ & $\mathrm{X}$ & $\mathrm{X}$ & $\mathrm{X}$ & & $\mathrm{X}$ \\
\hline
\end{tabular}

Analytics: $1=\mathrm{pH}$ measurement during precipitation, $2=$ mass balance, $3=$ Gel Permeation Chromatography, $4=$ Elemental Analysis (CHNS), $5=$ TGA/dTG, $6=$ DSC, $7=$ Gas Chromatography, $8={ }^{13} \mathrm{C}$ NMR, $9={ }^{1} \mathrm{H}$ and $2 \mathrm{D}$ HSQC, $10=$ ATR-FTIR (results not shown). 

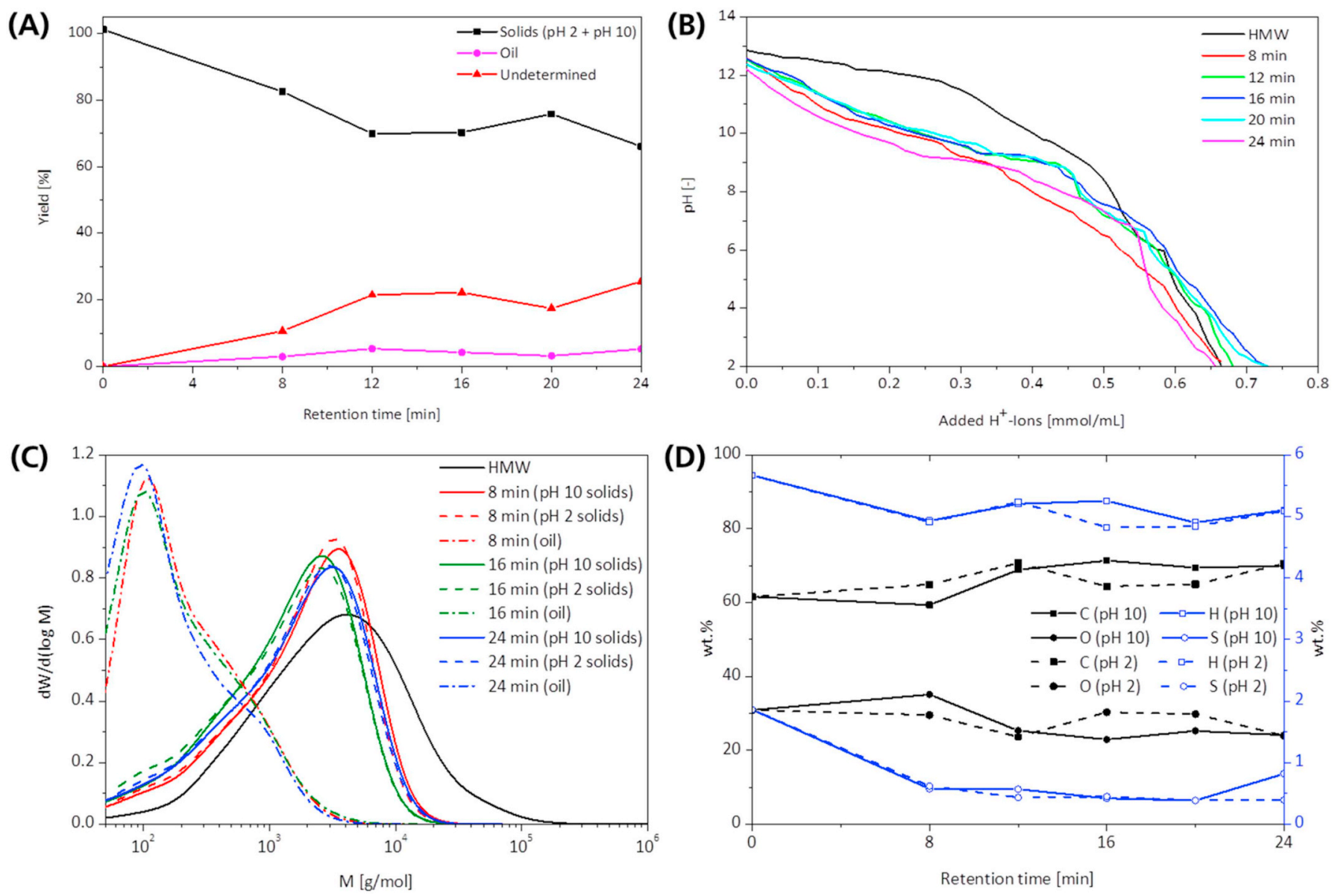

Fig. 1. (A) Yields of solids, oil, and undetermined compounds over increasing retention time; (B) Titration curves of the feed (HMW) and product solutions after all five retention times. The $\mathrm{pH}$ was lower with $5 \mathrm{M} \mathrm{HCl}$ (aq) that was added dropwise amounts of 0.5 to $1.0 \mathrm{~mL}$; (C) Molecular weight distributions of solids precipitated at $\mathrm{pH} 10, \mathrm{pH} 2$ and of the oil phases after reactions with retention times of 8, 16, and $24 \mathrm{~min}$; and (D) Elemental composition as a function of retention time for $\mathrm{pH} 10$ and $\mathrm{pH} 2$ solids. Carbon and oxygen are shown on the left axis, hydrogen and sulphur on the right. Trends of pH 10 and pH 2 solids are comparable.

\subsection{Thermal analysis}

Thermogravimetric analysis (TGA/dTG) and Differential Scanning Calorimetry (DSC) analyses of the $\mathrm{pH} 10$ and $\mathrm{pH} 2$ solids demonstrate that after heating the solid residues, the mass fractions at $T=600{ }^{\circ} \mathrm{C}$ and $800^{\circ} \mathrm{C}$ were ca. $10-15 \%$ higher compared to the feed (HMW), and generally increase with retention time (Fig. 2(a-d), Table S3, S4 and Fig. S1). It can be seen that the greatest mass loss occurs in the interval $T=300$ to $500^{\circ} \mathrm{C}$, with a shoulder in the range $T=240-290^{\circ} \mathrm{C}$ and a maximum rate of weight loss for the initial residue at a temperature of $362^{\circ} \mathrm{C}$ and on average for the $\mathrm{pH} 2$ and $\mathrm{pH} 10$ fractions of $389^{\circ} \mathrm{C}$ and $393^{\circ} \mathrm{C}$ (Fig. 2(a and b)). It can therefore be seen that residue thermal
Table 3

Elemental composition and proposed molecular formula of the compounds missing in the mass balance.

\begin{tabular}{lllllll}
\hline $\begin{array}{l}t_{\text {retention }} \\
{[\mathrm{min}]}\end{array}$ & $\begin{array}{l}\text { Total lost } \\
\text { mass }[\mathrm{g}]\end{array}$ & $\mathrm{C}[\mathrm{g}]$ & $\mathrm{H}[\mathrm{g}]$ & $\mathrm{O}[\mathrm{g}]^{\mathrm{a}}$ & $\mathrm{S}[\mathrm{g}]$ & Molecular formula \\
\hline 8 & 3.03 & 1.91 & 0.31 & 0.52 & 0.29 & $\mathrm{C}_{1.00} \mathrm{H}_{1.93} \mathrm{O}_{0.20} \mathrm{~S}_{0.06}$ \\
12 & 5.25 & 2.00 & 0.37 & 2.56 & 0.32 & $\mathrm{C}_{1.00} \mathrm{H}_{2.21} \mathrm{O}_{0.96} \mathrm{~S}_{0.06}$ \\
16 & 5.40 & 2.45 & 0.41 & 2.20 & 0.33 & $\mathrm{C}_{1.00} \mathrm{H}_{2.01} \mathrm{O}_{0.67} \mathrm{~S}_{0.05}$ \\
20 & 4.38 & 2.08 & 0.39 & 1.58 & 0.34 & $\mathrm{C}_{1.00} \mathrm{H}_{2.23} \mathrm{O}_{0.57} \mathrm{~S}_{0.06}$ \\
24 & 6.03 & 2.42 & 0.43 & 2.86 & 0.32 & $\mathrm{C}_{1.00} \mathrm{H}_{2.12} \mathrm{O}_{0.89} \mathrm{~S}_{0.05}$ \\
\hline
\end{tabular}

${ }^{\text {a }}$ Calculated by difference.

Table 2

Molecular weight distributions of products from reactions where $t_{\text {Ret }}=8,16$, and 24 mins.

\begin{tabular}{|c|c|c|c|c|c|c|c|c|c|}
\hline \multirow{2}{*}{$\begin{array}{l}\mathrm{t}_{\text {retention }} \\
{[\mathrm{min}]}\end{array}$} & \multicolumn{3}{|c|}{ pH 10 solids } & \multicolumn{3}{|c|}{ pH 2 solids } & \multicolumn{3}{|l|}{ Oil } \\
\hline & $\begin{array}{l}M_{W} \\
{[\mathrm{~g} / \mathrm{mol}]}\end{array}$ & $\begin{array}{l}M_{N} \\
{[\mathrm{~g} / \mathrm{mol}]}\end{array}$ & $\begin{array}{l}P D I \\
{[-]}\end{array}$ & $\begin{array}{l}M_{W} \\
{[\mathrm{~g} / \mathrm{mol}]}\end{array}$ & $\begin{array}{l}M_{N} \\
{[\mathrm{~g} / \mathrm{mol}]}\end{array}$ & $\begin{array}{l}P D I \\
{[-]}\end{array}$ & $\begin{array}{l}M_{W} \\
{[\mathrm{~g} / \mathrm{mol}]}\end{array}$ & $\begin{array}{l}M_{N} \\
{[\mathrm{~g} / \mathrm{mol}]}\end{array}$ & $\begin{array}{l}P D I \\
{[-]}\end{array}$ \\
\hline 8 & 3020 & 710 & 4.2 & 2800 & 680 & 4.1 & 360 & 150 & 2.4 \\
\hline 16 & 2380 & 600 & 3.9 & 2210 & 520 & 4.3 & 360 & 140 & 2.6 \\
\hline 24 & 2660 & 610 & 4.4 & 2650 & 590 & 4.5 & 310 & 130 & 2.4 \\
\hline HMW (feed) & 7460 & 1170 & 6.4 & & & & & & \\
\hline
\end{tabular}



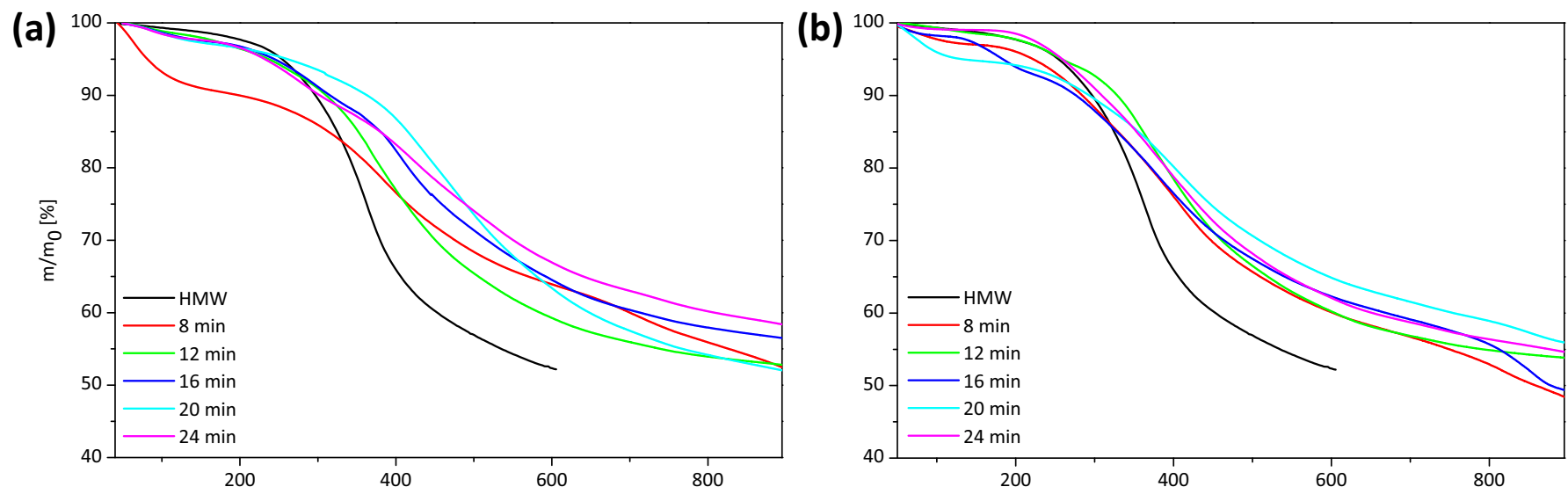

(c)

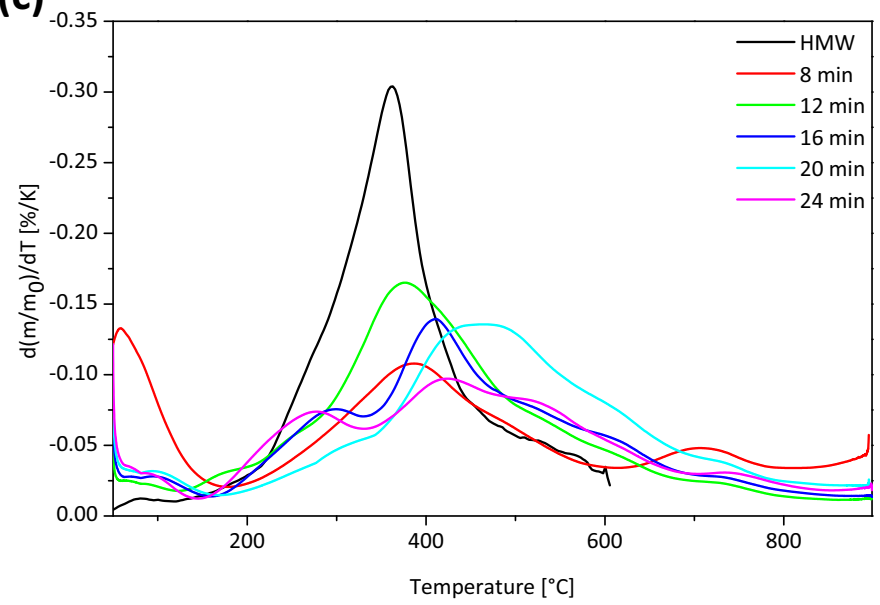

(d)

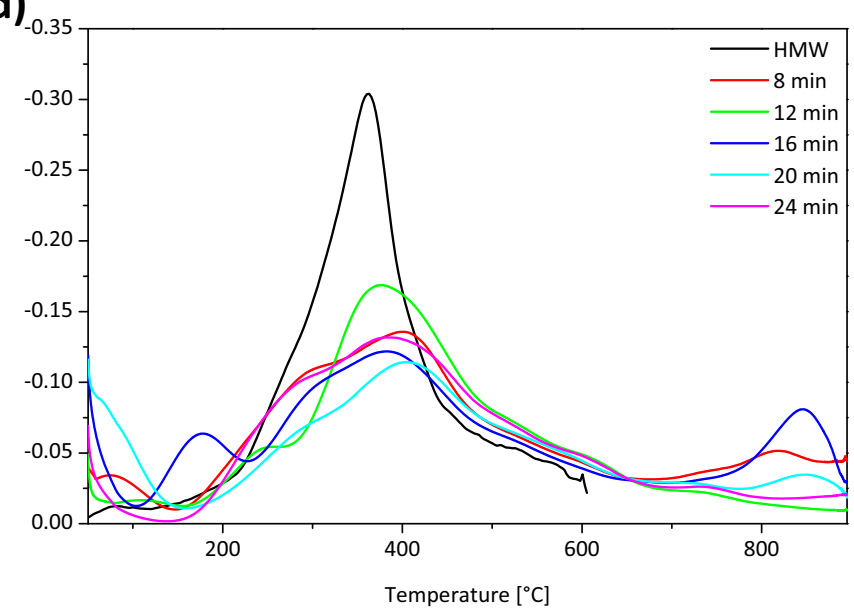

Fig. 2. TGA and dTG of pH 10 (a, c) and the pH 2 solids (b, d). Residue at $600{ }^{\circ} \mathrm{C}$ is increased compared to the feed and over retention time. The dTG is multimodal compared to the mono-modal distribution of the feed.

stability is generally higher than the starting material. However, it can also be seen that the $d \mathrm{TG}$ peak distribution is more heterogeneous with a multi-modal distribution compared to the feed that features one maximum in the $d \mathrm{TG}$ trace (Fig. $2(\mathrm{c}+\mathrm{d})$ ).

To be able to better understand the thermal events occurring, the $d$ TG traces were deconvoluted (Fig. S2 and S3). The P1 peak (not included) was assumed to be trace water. The peak, P2 for the HMW and $\mathrm{pH} 2$ and $\mathrm{pH} 10$ solids have an average temperature of decomposition of, $263^{\circ} \mathrm{C}, 282^{\circ} \mathrm{C}$ and $270^{\circ} \mathrm{C}$ respectively. Based on the previous report (Wittkowski et al., 1992) this is proposed to be related to propanoid side chain degradation, leading to ferrulic acid, methyl, ethyl and vinyl guaiacol and potentially vanillin formation. Interestingly it can be seen that peak 3 (P3) for both the $\mathrm{pH} 2$ and $\mathrm{pH} 10$ residues ceases to exist after $12 \mathrm{~min}$. This peak with a temperature of decomposition over the range $T=325-365^{\circ} \mathrm{C}$ is proposed to be associated with hemicelluloses (Li et al., 2017) (This assertion is supported by NMR analysis; see Section 3.5). The main peak P4 generally increases in stability where $\mathrm{t}_{\mathrm{ret}} \leq 12 \mathrm{~min}$ and could be related to the removal of $-\mathrm{OCH}_{3}$ groups and subsequent conversion of "phenolics" to catechol derivatives etc. Higher temperature peaks are likely related to the degradation of more stable lignin structures or of secondary degradation products, whilst P7 is associated with char formation.

DSC was performed for the runs \#K1, \#K3, and \#K2 with $\mathrm{t}_{\mathrm{ret}}=8$, 16, and 24 min, respectively (Fig. 3(a)), except for the $\mathrm{pH} 10$ fraction $t_{\text {ret }}=24 \mathrm{~min}$, where there was too little sample to be able to test. Additionally, the $\mathrm{pH} 2$ solids at $\mathrm{t}_{\mathrm{ret}}=16 \mathrm{~min}$ and the $\mathrm{MeOH}$ soluble fraction
(LMW) were mixed at a 1:1 w:w ratio to see if the LMW could serve as a plasticiser. The glass transition temperatures $\left(\mathrm{T}_{\mathrm{g}}\right.$ ) for the KL, LMW, HMW samples were found to be 147,121 and $169^{\circ} \mathrm{C}$ respectively. As expected $\mathrm{T}_{\mathrm{g}}$ of the HMW fraction is higher due to it being comprised of larger MW lignin fractions, resulting in a lower free volume (Culebras et al., 2018). For the $\mathrm{pH} 2$ and $\mathrm{pH} 10$ precipitated solids after $\mathrm{HBCD}$, where $\mathrm{t}_{\mathrm{ret}}=8$, 16 , and $24 \mathrm{~min}$, a clear glass transition cannot be determined. For the LMW fraction $+\mathrm{pH} 2$, when $\mathrm{t}_{\text {ret }}=16$ min, a faint $\mathrm{T}_{g}$ can be determined at $123^{\circ} \mathrm{C}$, suggesting that the LMW is not acting as a plasticiser due to there being very little difference between the $\mathrm{T}_{g}$ of $\mathrm{LMW}$ and this sample. Bengtsson et al. co-spinning of KL and cellulose as a polymer blend (Bengtsson et al., 2018). This would lower carbon content, but can increase linearity and thus stability of the resulting fibre.

\subsection{Gas chromatography}

Evolution of four calibrated compounds in the oil fraction as a function of $t_{\text {ret }}$ was investigated as analysed through Gas Chromatography (GC) (Fig. 3(b)). Catechol and its derivatives were found to accumulate while guaiacol derivatives as vanillin and acetovanillone were shown to slightly decrease (e.g. acting as a precursor for the catecholic compounds). The GC detectable amount of 4-methylcatechol was found to be significantly higher than that of 3-methylcatechol, suggesting that the $-\mathrm{CH}_{3}$ group at the para-position prevents further methylation and probably originates as a residual group after demethoxylation of guaiacylic compounds with functional group 

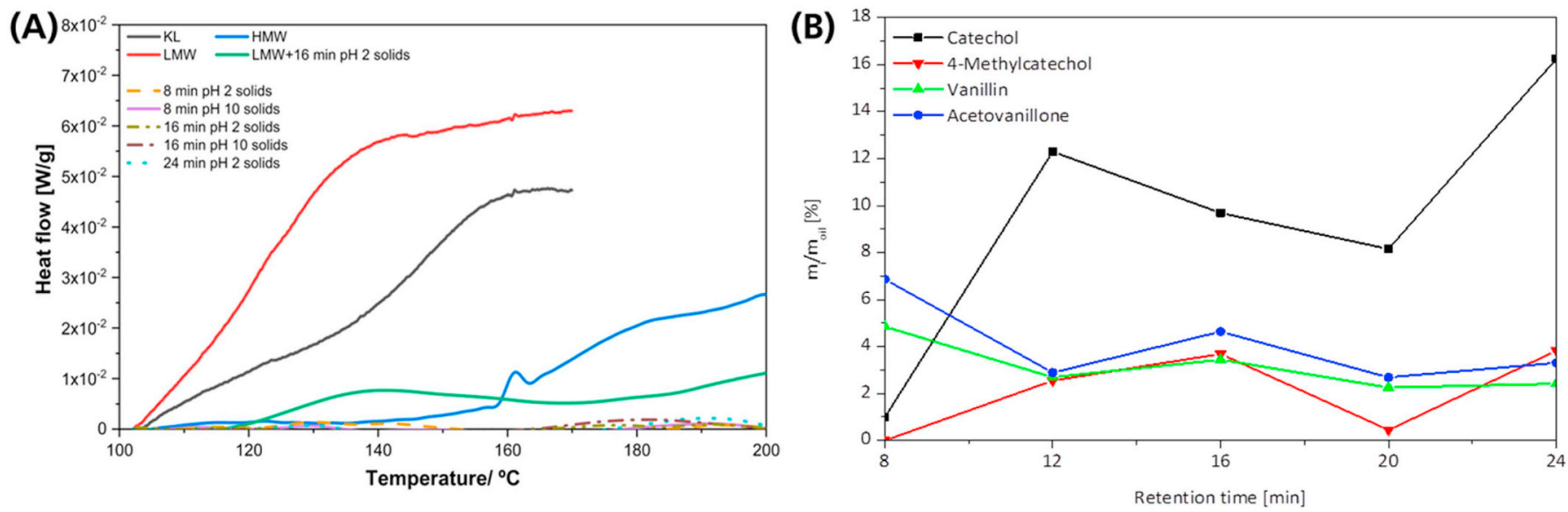

(C)

(D)
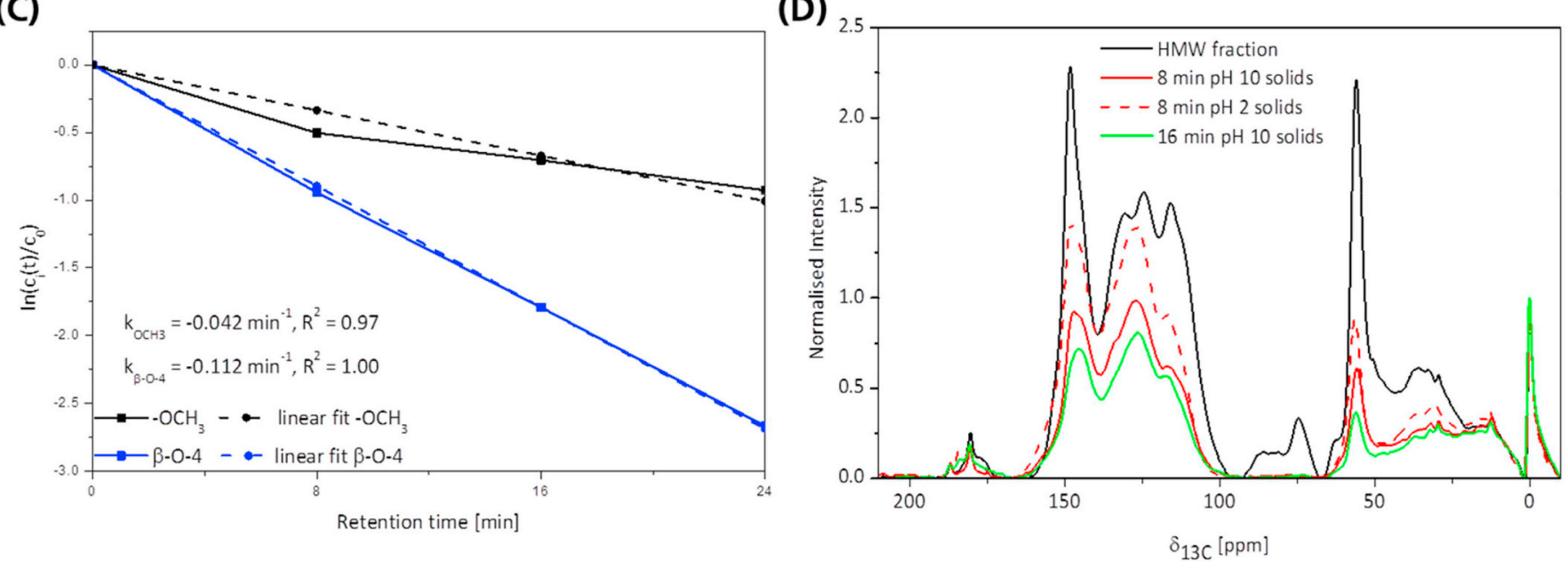

Fig. 3. (A) DSC traces of the precipitated solids after retention times 8, 16, and 24 min compared to the original KL, MeOH insoluble fraction (HMW, feed); and $\mathrm{MeOH}$ soluble fraction (LMW); (B) Main GC detectable compounds in the oil fractions over retention time; (C) $\ln \left(\mathrm{c}_{\mathrm{i}}(\mathrm{t}) / \mathrm{c}_{0}\right)$ over retention time of the concentrations of the side chain groups of the $\mathrm{pH} 10$ solids determined by $2 \mathrm{D}$ HSQC. The values for $\mathrm{k}$ are given in the figure along with the $\mathrm{R}^{2}$ of the linear fit; and (D) Solid state ${ }^{13} \mathrm{C}$ CP MAS NMR spectra of the \#K1 pH 10 and $\mathrm{pH} 2$ solids $\left(\mathrm{t}_{\mathrm{ret}}=8 \mathrm{~min}\right)$ and \#B1 $\mathrm{pH} 10$ solids $\left(\mathrm{t}_{\mathrm{ret}}=16 \mathrm{~min}\right)$.

at the para-position (e.g. vanillin or acetovanillone).

\subsection{Nuclear magnetic resonance spectroscopy analysis}

${ }^{1} \mathrm{H}$ and 2D Heteronuclear Single Quantum Correlation (HSQC) NMR analyses were to (semi-) quantify functional group content (i.e. via usage of the deuterated solvent as internal standard; Fig. 4(c); (a-d). The presented 2D HSQC spectra provide information regarding the feed (HMW) and at $\mathrm{t}_{\text {ret }}=8,16$, and $24 \mathrm{~min}$ respectively, whilst further focus can be given on aliphatic side chain content (Fig. 5(a-d)). Regarding the latter, the content is strongly increased as a consequence of processing, which also explains the higher solubility in organic solvents (e.g. as described by the group contribution theory (Hansen, 2007)). It was observed that aliphatics were added at $\alpha$ and $\beta$ positions relative to aromatic rings. It is interesting to note that no $\mathrm{Ar}-\mathrm{CH}_{2}-\mathrm{Ar}$ bonds are observed at $\delta_{1 \mathrm{H}}=3.5 \mathrm{ppm}, \delta_{13 \mathrm{C}}=30-40 \mathrm{ppm}$ (except in the recovered oil phase) (Huang et al., 2015). Repolymerisation during hydrothermal treatment of lignin is supposed to take place via formaldehyde as in the production of phenyl formaldehyde (Chakar and Ragauskas, 2004). This seems not to be a predominant reaction under basic hydrothermal conditions.

The ${ }^{1} \mathrm{H}$ NMR can yield additional information compared to the 2D HSQC, since it also shows protons not bound to a carbon atom. Fig. S4 shows the ${ }^{1} \mathrm{H}$ spectrum of the $\mathrm{pH} 10$ solids and six representative areas used for integration and comparison in Fig. 6. The areas are normalised on DMSO-d6 and trends for $\mathrm{pH} 10$ and $\mathrm{pH} 2$ are comparable. As with the ${ }^{13} \mathrm{C}$ NMR, total areas are significantly smaller as compared to the feed spectrum. Peaks in area a2 and a4 belonging to aldehydes and remaining (hemi-)celluloses respectively, are almost completely removed at $t_{\text {ret }}=8 \mathrm{~min}$. Area a 5 consists mainly of protons bound in oxygenated side-chains of aromatic compounds and exhibits a gradual decrease over retention time. The right most area a6 represents aliphatic sidechains. It can be seen that lignin undergoes self-alkylation under the applied HBCD conditions. A complete removal of resonances between $4 \mathrm{ppm}<\delta_{1 \mathrm{H}}<6 \mathrm{ppm}$ at $\mathrm{t}_{\text {ret }}=8 \mathrm{~min}$ is observed (Fig. S4). These represent mainly protons in residual (hemi) celluloses. Furthermore, the total height of $\delta_{1 \mathrm{H}}=3.5 \mathrm{ppm}$ is reduced and the lower shift shouldering disappears at $t_{\text {ret }}=16 \mathrm{~min}$. The broad spectral feature of the HMW fraction is split into two resolved resonances at $\delta_{1 \mathrm{H}}=3.81$ and $3.75 \mathrm{ppm}$. These are also visible as two separate resonances in the $2 \mathrm{D}$ HSQC (Fig. S5). When fitting the $-\mathrm{OCH}_{3} / \mathrm{DMSO}$ and $\beta-\mathrm{O}-4 / \mathrm{DMSO}$ signals over a logarithmic plot, these two reactions appear as a first order reaction with reaction rate of the $\beta-\mathrm{O}-4$ removal three times larger than that of the $\mathrm{MeO}$-group removal (Fig. 3(c)).

Complimentarily to the above analysis, a solid state ${ }^{13} \mathrm{C}$ CP MAS NMR spectrum was acquired for the solids recovered for $t_{\text {ret }}=8$ min. 

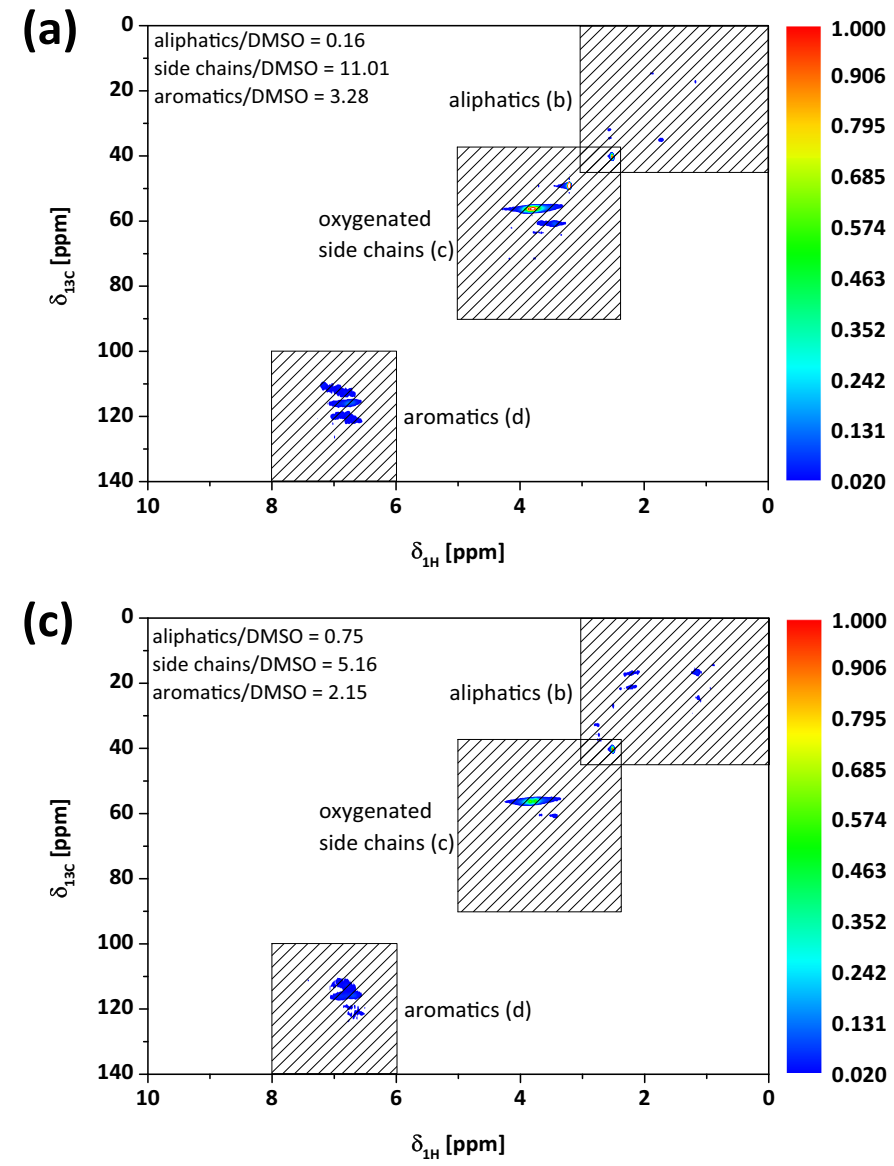
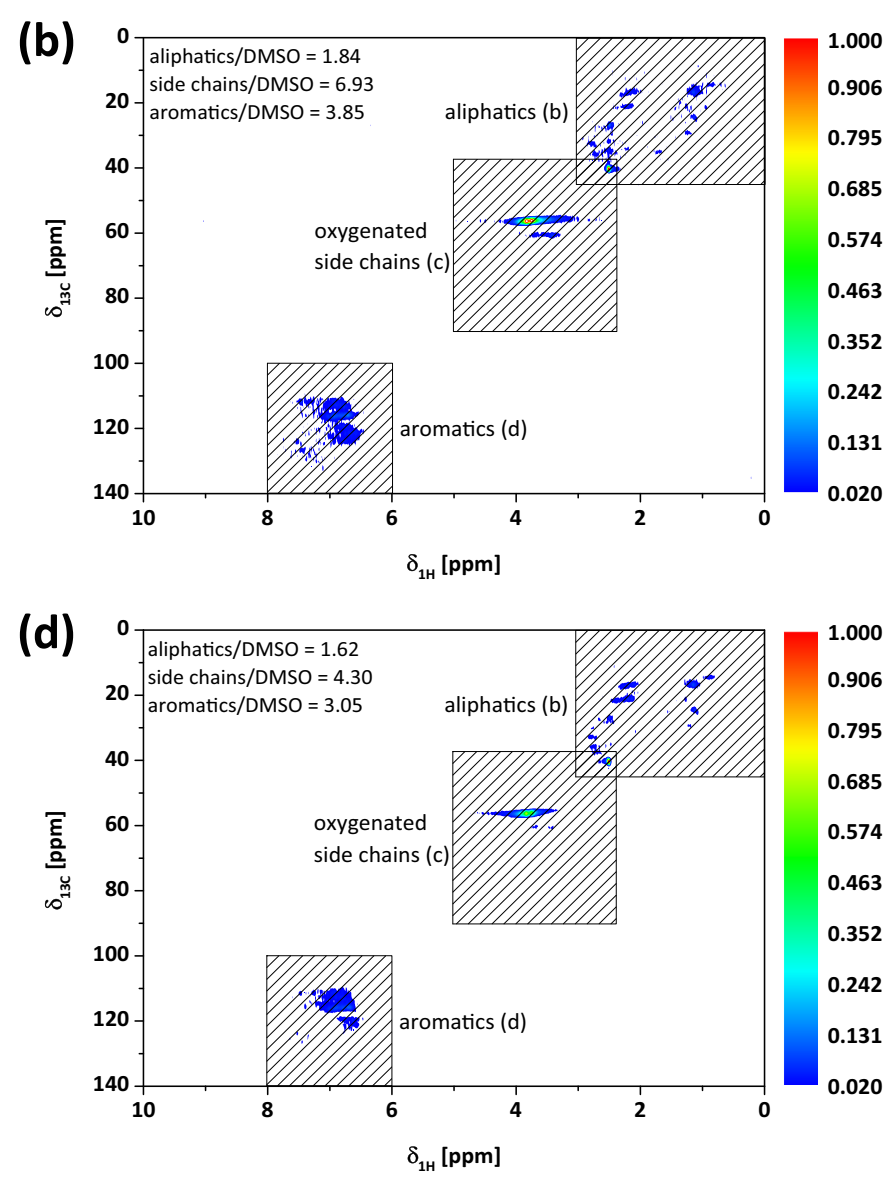

Fig. 4. 2D HSQC NMR spectra overview: (a) HMW fraction; pH 10 solids recovered at $t_{\text {ret }}=$ (b) 8 , (c) 16 , and (d) 24 min.

Characterisation of the $\mathrm{pH} 10$ solids at $t_{\text {ret }}=16$ min was used for comparison (as reported previously by our group; Fig. 3(d)) (Otromke et al., 2018). As can be observed (echoing our previously reported results), removal of spectral region associated with side chains, a strong decrease of $-\mathrm{OCH}_{3}$ resonances as well as a reduction in the overall total aromatic region intensity is observed as a consequence of the HBCD processing at increasing $t_{\text {ret }}$. For $t_{\text {ret }}=8$ and 16 min it appears that resonances associated with side chains in the region $\delta_{13 \mathrm{C}}=80$ to $60 \mathrm{ppm}$ are completely removed in the initial $8 \mathrm{~min}$. The decrease of relative intensity of resonances in the aromatic region and of $-\mathrm{OCH}_{3}$ resonances is only slightly stronger for $\mathrm{t}_{\mathrm{ret}}=16 \mathrm{~min}$ for the $\mathrm{pH} 10$ solids as compared to the equivalent $t_{r e t}=8$ min sample.

Taking into account information provided in our recent report (i.e. where a higher thermal stability, a lower molecular weight, and a strong reduction in $-\mathrm{OCH}_{3}$ groups were the main findings for the solid precipitates; (Otromke et al., 2018)), 2D HSQC, ${ }^{1} \mathrm{H}$ NMR, and thermal analyses of retention time-dependent reactions provide further insights into the chemical changes occurring during HBCD. Contrastingly, based on the collected results, the oil fraction seems reasonably stable in comparison to the solid fraction. The corresponding HMW peak is very broad in GPC analysis prior to HBCD treatment, becoming significantly narrower after treatment with a shift in the maximum. Regarding thermal stability, this alters according with the observed changes in Mw as complimented by the observed chemical changes at the molecules scale (e.g. from NMR analysis). Mass balance shows a loss of ca.
20-25 wt $\%$ for all except when $t_{\text {ret }}=8 \mathrm{~min}$, where the loss accumulates to $10 \mathrm{wt} \%$. TGA shows a slight increase in residual solids over retention time at $T=600$ and $800^{\circ} \mathrm{C}$. DSC traces for the precipitated solids were found not to present any clear glass transitions (up to $200^{\circ} \mathrm{C}$ ). In addition, the mixture consisting of the $\mathrm{pH} 2$ solids with $\mathrm{t}_{\text {ret }}=16 \mathrm{~min}$ and the LMW fraction (1:1, w:w) showed that the LMW does not act as a plasticiser. ${ }^{1} \mathrm{H}$ and $2 \mathrm{D}$ HSQC NMR showed a significant increase in alkylation in the solid product after reaction leading to an increased solubility in organic solvents. The ${ }^{1} \mathrm{H}$ NMR also indicates a significant decrease for resonances associated with the "phenolic" (i.e. $\delta_{1 \mathrm{H}}=9.35$ to $8.00 \mathrm{ppm})$ and "aromatic" region $\left(\delta_{1 \mathrm{H}}=8.00\right.$ to $\left.6.00 \mathrm{ppm}\right)$, which concurs well with ${ }^{13} \mathrm{C}$ CP MAS NMR analysis. This indicates that an increase in $t_{r e t}$ influences the precipitated solids, as an increased demethoxylation and cleavage of ether linkages are observed, while thermal properties and molecular weight distributions are less affected (Table 2). Over the different retention times investigated in this study, no hints at extensive condensation or polymerisation reactions could be observed. Regarding potential processing to CFs, the lack of a glass transition means, that solvent spinning would be the preferred method.

\section{Techno-economic analysis}

A preliminary techno-economic evaluation of the HBCD process described in our previous report and current article is provided in the context of its potential implementation in a Kraft mill equipped with 

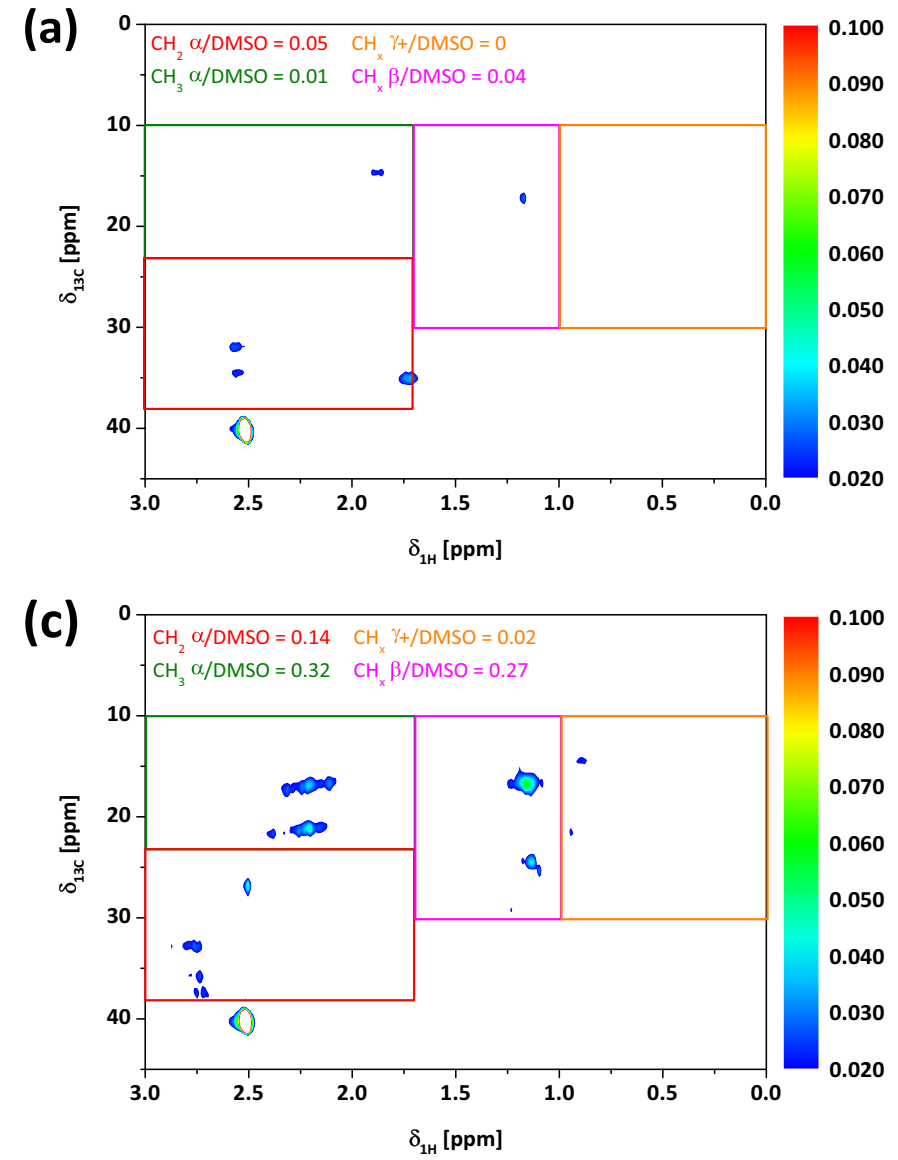
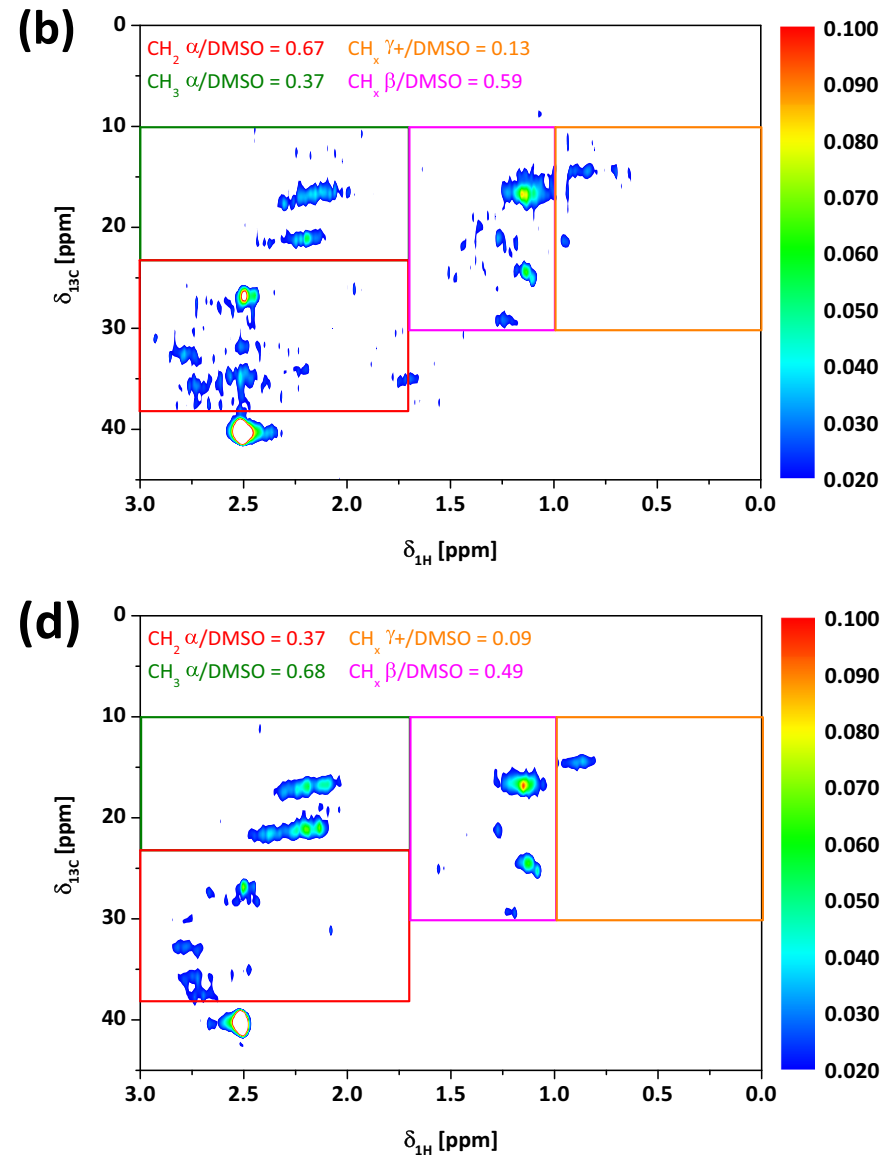

Fig. 5. 2D HSQC NMR spectra of the aliphatics region: HMW fraction (a); pH 10 solids at $t_{\text {ret }}=$ (b) 8 ; (c) 16 ; and (d) 24 min.

LignoBoost $^{\oplus}$ technology (Otromke et al., 2018). The HBCD process uses chemicals, equipment, and conditions that should be either present in a Kraft pulp mill or can be easily acquired and installed with existent know-how. It is assumed that the plant can provide $75 \mathrm{t} / \mathrm{d}$ of KL feed, containing ca. $26 \mathrm{wt} \%$ of $\mathrm{H}_{2} \mathrm{O}$.

Table 4 provides general data for the simulation and assumptions concerning prices for commodities and energy. A process flow sheet is provided (Fig. S6) based on the corresponding mass and energy flow rates (Table S5 and Table S6).

In a first step, lignin is dried to $5 \mathrm{wt} \%$ residual $\mathrm{H}_{2} \mathrm{O}$ and then extracted via $\mathrm{MeOH}$ in a continuous stirred tank reactor (CSTR 1). The dispersion is filtered and the retentate dried to remove and recover the $\mathrm{MeOH}$ (Dryer 2). From the permeate, the $\mathrm{MeOH}$ is removed via complete evaporation and fed back into the process. Stream 102 gives ca. $100 \mathrm{~kg} / \mathrm{h}$ of $\mathrm{H}_{2} \mathrm{O}$ that would accumulate in the $\mathrm{MeOH}$. An acceptable amount of $\mathrm{H}_{2} \mathrm{O}$ in the $\mathrm{MeOH}$ is assumed based on technical and economic feasibility. It is assumed that some $\mathrm{H}_{2} \mathrm{O}$ accumulates in a feedback loop and some will exit via stream 7 , but an additional $\mathrm{MeOH}$ rectification might become necessary. The LMW fraction (MeOH soluble) is determined as $2^{\circ}$ product and contains $5 \mathrm{wt} \%$ residual $\mathrm{H}_{2} \mathrm{O}$. After drying, the HMW fraction is dispersed and dissolved at $10 \mathrm{wt} \%$ in a $1 \mathrm{M} \mathrm{NaOH}$ (aq) solution. This results in $16 \mathrm{~m}^{3} / \mathrm{h}$ of feed solution, which will be brought to 180 bar via a piston membrane pump and is pumped through a plug flow reactor (PFR) with a retention time of $10 \mathrm{~min}$ (streams 10 and 11). Temperature is set at $325^{\circ} \mathrm{C}$, and two serial tube bundle heat exchangers with DN250 tubes and a length of $5800 \mathrm{~mm}$ each are used for the heat transfer. The hot liquid at the exhaust is used to heat the feed and an efficiency of $90 \%$ is assumed. The pressure in the PFR is kept at 180 bar with an overflow valve. The product is precipitated with $\mathrm{CO}_{2}$ in CSTR 3, filtered and re-dispersed in CSTR 4, where it is washed with a pH $2.5 \mathrm{H}_{2} \mathrm{SO}_{4}$ (aq) composed of $10 \mathrm{wt}$ $\%$ solids. After washing, a last filtration and drying step is included. The precipitation and washing procedure is comparable to the LignoBoost ${ }^{\circledast}$ process and enables the usage of similar equipment and already present know-how (Johnson and Hart, 2016; Tomani, 2010). The permeate of the washing solution and low $\mathrm{pH} \mathrm{H}_{2} \mathrm{O}$ is fed to the recovery cycle of the pulp mill and contains $324 \mathrm{~kg} / \mathrm{h}$ of $\mathrm{H}_{2} \mathrm{O}$ solubles originating from the lignin. Additionally, $588 \mathrm{~kg} / \mathrm{h}$ of $\mathrm{NaOH}$ and $323 \mathrm{~kg} / \mathrm{h}$ of $\mathrm{CO}_{2}$ will be fed into the recovery process. A recovery rate for $\mathrm{NaOH}$ of $95 \%$ is assumed (Tran and Vakkilainnen, 2007), while $\mathrm{CO}_{2}$ and $\mathrm{H}_{2} \mathrm{SO}_{4}$ are considered not recoverable. These compounds will most likely be present as $\mathrm{Na}_{2} \mathrm{CO}_{3}, \mathrm{NaHCO}_{3}, \mathrm{SO}_{4}{ }^{2-}$, plus some additional $\mathrm{H}_{2} \mathrm{O}$ formed via recombination of $\mathrm{H}_{3} \mathrm{O}^{+}$with $\mathrm{OH}^{-}$. Additionally, $1 \%$ of the $\mathrm{MeOH}$ is considered to be lost. Stream 203 (to the recovery boiler) contains ca. $25 \mathrm{~m}^{3} / \mathrm{h}$ of $\mathrm{H}_{2} \mathrm{O}$. The process will be charged the necessary heat of evaporation for this amount of $\mathrm{H}_{2} \mathrm{O}$ with an efficiency of $90 \%$, while the LHV of the $\mathrm{H}_{2} \mathrm{O}$ solubles will be accounted for.

From this data, prices for the unit operation equipment were acquired from different companies (Table S7). In order to generate a first estimation of the costs, a factor of 4.5 for the inside battery limits (ISBL) 

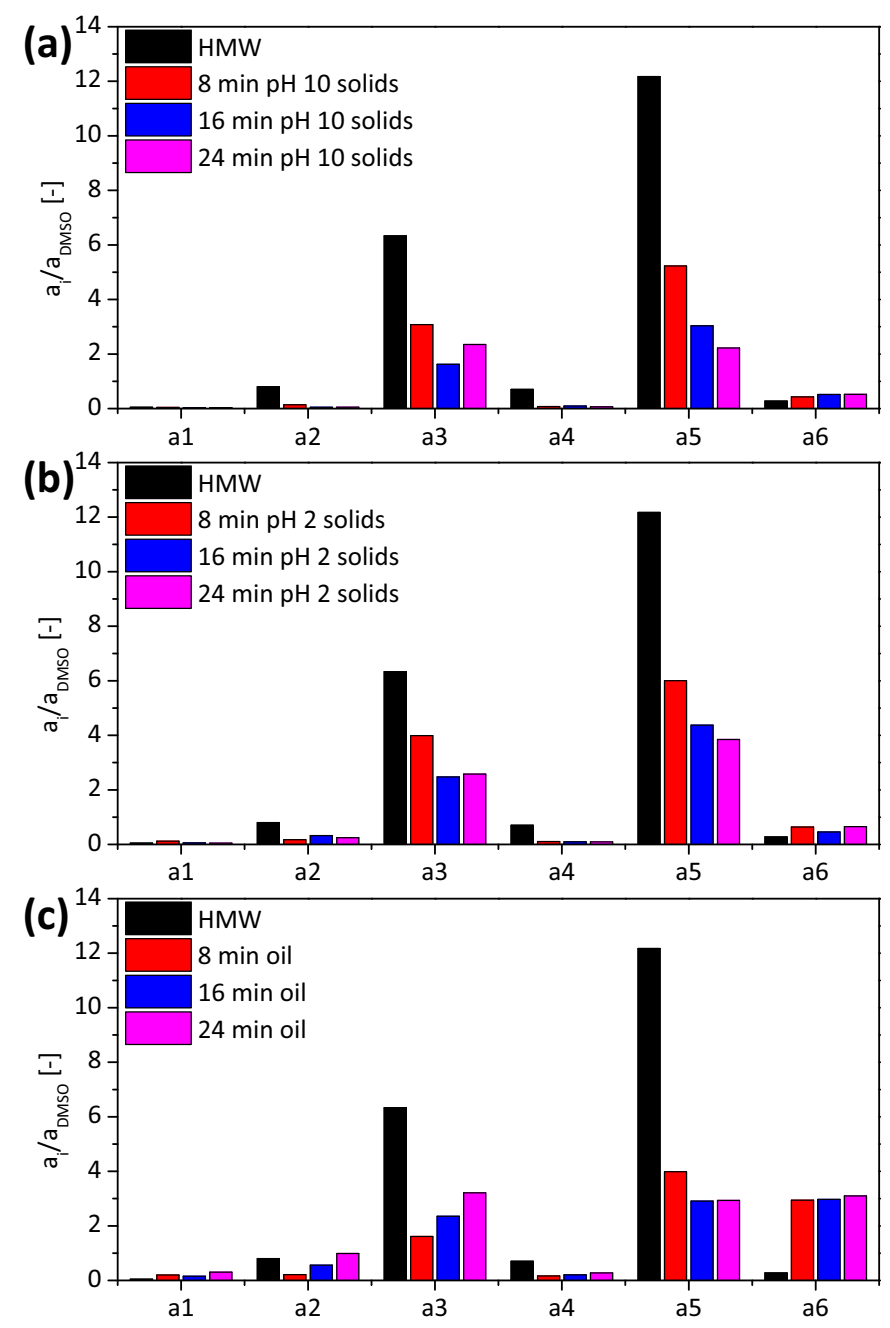

Fig. 6. DMSO-normalised area integration of the ${ }^{1} \mathrm{H}$ NMR spectra for (a) $\mathrm{pH} 10$ solids; (b) $\mathrm{pH} 2$ solids, and (c) the oil fractions. costs is used, which results in total investment costs of ca. $20 \mathrm{M€}$. For the investment, a construction time of two years and capital costs of $10 \%$ are assumed. The capital stems $50 \%$ from equity with $15 \%$ ROI and $50 \%$ from debt with an assumed interest rate of $5 \%$. Capital usage is split evenly across the two years. Depreciation is set linearly over ten years and $100 \%$ plant utilisation is established at $8000 \mathrm{~h} / \mathrm{a}$. Further fix costs are personnel (Table S8), taxes and insurance with 1.5\%, overhead with $1.5 \%$, and repairs and maintenance with $3 \%$ of the fixed capital costs (Table 5). Different scenarios for the by-product credits were envisioned:

1. Sold for $400 € / \mathrm{t}$, which is the price of the feed.

2. Has zero value.

3. Sold for $800 € / \mathrm{t}$, which is assumed as price for a substituent in phenyl formaldehyde.

4. Sold for the same price as the main product, when serving as a plasticiser.

Detailed product price calculations for the four scenarios are provided (Table S9). Scenario 1 is assumed to be the most realistic and leads to a product price of ca. $1600 € / \mathrm{t}$ which is increased to ca. 2000 $€ / t$ at $50 \%$ utilisation (Table S10). With a yield of 0.5 for the complete fibre production, which is in the range of (poly-)acrylonitrile (PAN) fibres, costs are between 2 and $4 € / \mathrm{kg}$ of CF.

\section{Conclusion}

Time dependent analysis of hydrothermal base catalysed treatment of technical Kraft lignin gave insights into structural changes of precipitated solids and the oil fraction. 2D HSQC NMR showed a strong decrease in methoxy groups and near complete removal of the remaining $\beta-O-4$ groups after 24 min. Alkylation increasing solubility in organic solvents and an increased thermal stability make the solid fraction an interesting candidate for solvent spinning of a bio-based fibre. A techno-economic analysis revealed feedstock, depreciation, and heat as the main cost drivers and an estimated sales price with an ROI of $10 \%$ of ca. $1600 € / \mathrm{t}$

Table 4

General data for the techno economic evaluation of the process.

\begin{tabular}{|c|c|c|c|}
\hline \multicolumn{2}{|l|}{ Assignment } & Definition/symbol & Value \\
\hline \multicolumn{2}{|l|}{ Feed mass flow } & $\dot{\mathrm{m}}_{\text {feed }}$ & $75 \mathrm{t} / \mathrm{d}$ \\
\hline \multicolumn{2}{|c|}{ Lignin $\mathrm{H}_{2} \mathrm{O}$ content } & $\frac{\dot{m}_{\mathrm{H} 2 \mathrm{O}}}{\dot{\mathrm{m}}_{\text {lignin }}+\dot{\mathrm{m}}_{\mathrm{H} 2 \mathrm{O}}} / \omega_{\mathrm{H} 2 \mathrm{O}, 1}$ & 0.26 \\
\hline \multicolumn{2}{|c|}{ Lignin $\mathrm{H}_{2} \mathrm{O}$ content after drying } & $\frac{\mathrm{m}_{\mathrm{H} 2 \mathrm{O}}}{\mathrm{m}_{\text {lignin }}+\mathrm{m}_{\mathrm{H} 2 \mathrm{O}}} / \omega_{\mathrm{H} 2 \mathrm{O}, 2}$ & 0.05 \\
\hline \multicolumn{2}{|c|}{ Lignin lower heating value } & $\mathrm{LHV}_{\text {lignin }}$ & $15 \mathrm{MJ} / \mathrm{kg}$ \\
\hline \multicolumn{2}{|c|}{$\mathrm{MeOH}$ per lignin for extraction } & $\frac{\dot{m}_{\text {lignin }}}{\dot{\mathrm{V}}_{\mathrm{MeOH}}}$ & $250 \mathrm{~kg} / \mathrm{m}^{3}$ \\
\hline \multicolumn{2}{|c|}{ Ratio of fractions after extraction } & $\frac{\mathrm{m}_{H M W}}{\dot{\mathrm{m}} \mathrm{LMW}}$ & $7 / 3=2.33$ \\
\hline \multirow[t]{3}{*}{ Retention times } & $\begin{array}{l}\mathrm{MeOH} \\
\text { extraction }\end{array}$ & $\tau_{\mathrm{MeOH}}$ & $15 \mathrm{~min}$ \\
\hline & $\begin{array}{l}\mathrm{CO}_{2} \\
\text { precipitation }\end{array}$ & $\tau_{\mathrm{CO} 2}$ & $30 \mathrm{~min}$ \\
\hline & $\mathrm{H}_{2} \mathrm{SO}_{4}$ washer & $\tau_{\mathrm{H} 2 \mathrm{SO} 4}$ & $5 \mathrm{~min}$ \\
\hline \multicolumn{2}{|l|}{ Loss of $\mathrm{MeOH}$} & 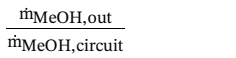 & 0.01 \\
\hline \multicolumn{2}{|c|}{ Compounds the HMW fraction is reacted into } & $\dot{\mathrm{m}}_{\text {product }}+\dot{\mathrm{m}}_{\mathrm{H} 2 \mathrm{O} \text { solubles }}$ & \\
\hline \multicolumn{2}{|c|}{ Mass of $\mathrm{CO}_{2}$ needed to precipitate $1 \mathrm{~kg}$ of product } & $\frac{\dot{\mathrm{m}}_{\mathrm{CO} 2}}{\mathrm{~m}_{\text {product }}}$ & 0.5 \\
\hline \multicolumn{2}{|c|}{ Amount of lignin precipitated with $\mathrm{CO}_{2}$ after reaction } & $\dot{\mathrm{m}}_{\text {product }}$ & 0.8 \\
\hline
\end{tabular}


Table 4 (continued)

\begin{tabular}{|c|c|c|c|}
\hline Assignment & & Definition/symbol & Value \\
\hline \multirow[t]{8}{*}{ Prices } & Feed/Lignin & $\mathrm{p}_{\text {feed }}$ & $400 € / \mathrm{t}$ \\
\hline & $\mathrm{MeOH}$ & $\mathrm{p}_{\mathrm{MeOH}}$ & $250 € /$ t(Methanex, n.d.) \\
\hline & $\mathrm{CO}_{2}$ & $\mathrm{P}_{\mathrm{CO} 2}$ & $90 € /$ t(Tomani, 2010) \\
\hline & $\mathrm{NaOH}$ & $\mathrm{p}_{\mathrm{NaOH}}$ & $320 € /$ t(alibaba.com, n.d.-a, n.d.-b) \\
\hline & $\mathrm{H}_{2} \mathrm{SO}_{4}(96 \%)$ & $\mathrm{p}_{\mathrm{H} 2 \mathrm{SO}} 4$ & $200 € /$ t(alibaba.com, n.d.-a, n.d.-b) \\
\hline & Heat & pheat & $0.01 € / \mathrm{kWh}^{\mathrm{a}}$ \\
\hline & Electricity & pelec & $0.04 € / \mathrm{kWh}$ (Pescia and Reidl, 2014) \\
\hline & $\mathrm{H}_{2} \mathrm{O}$ & $\mathrm{p}_{\mathrm{H} 2 \mathrm{O}}$ & $0.35 € / \mathrm{t}^{\mathrm{b}}$ \\
\hline
\end{tabular}

${ }^{\text {a }}$ LHV natural gas $10.5 \mathrm{kWh} / \mathrm{m}^{3}$, price natural gas $2.50 \mathrm{USD} / \mathrm{MJ}($ Energy Information Administration, 2017), efficiency steam production 0.8;

b estimation from industry partners.

Table 5

Yearly absolute and relative variable and fix costs per tonne of product without by-product credits at an average utilisation of $8000 \mathrm{~h} / \mathrm{a}$.

\begin{tabular}{|c|c|c|c|c|c|}
\hline \multicolumn{3}{|c|}{ Variable costs } & \multicolumn{3}{|l|}{ Fix-costs } \\
\hline Type & {$\left[€ / t_{\text {product }}\right]$} & {$[\%]$} & Type & {$\left[€ / t_{\text {product }}\right]$} & [\%] \\
\hline Feed & 964 & 62 & Personnel & 54 & 3 \\
\hline $\mathrm{CO}_{2}$ & 45 & 3 & Depreciation & 179 & 12 \\
\hline $\mathrm{NaOH}$ & 15 & 1 & Taxes, insurance, overhead & 54 & 3 \\
\hline $\mathrm{H}_{2} \mathrm{SO}_{4}$ & $<1$ & $<1$ & Maintenance & 54 & 3 \\
\hline $\mathrm{H}_{2} \mathrm{O}$ & 7 & $<1$ & & & \\
\hline $\mathrm{CH}_{3} \mathrm{OH}$ & 14 & 1 & & & \\
\hline Heat & 159 & 10 & & & \\
\hline Electricity & 4 & $<1$ & & & \\
\hline$\underline{\text { Sum }}$ & 1209 & $\underline{78}$ & & $\underline{341}$ & 22 \\
\hline
\end{tabular}

\section{Acknowledgements}

RJW acknowledges financial support of the Fraunhofer Society and Fraunhofer Institute for Solar Energy Systems ISE through an "ATTRACT" award. PSS gratefully acknowledges the Spanish Ministry for Economy and Enterprise (MINECO) for a Ramón y Cajal fellowship (RYC-2014-16759) and a proyecto de I + D + I para jóvenes investigadores (MAT2014-59674-JIN). RJW and MO would also like to acknowledge the support of the joint Max Planck Society/Fraunhofer Society project "Dendrorefining". Dr. H. Scherer (AK Krossing; University of Freiburg, Germany) is thanked for his assistance with NMR measurements. The authors would like to thank the ICTP-CSIC characterisation service for their help in measuring the DSCs of the samples. The Fraunhofer IAP (Potsdam, Germany) is thanked for assistance with GPC measurements.

\section{Conflict of interest}

There exists no conflict of interest in this manuscript.

\section{References}

Aicher, T., Otromke, M., Rümmele, F., 2014. About the effect of hydrodynamics on aqueous phase reforming in packed-bed reactor systems. Chem. Ing. Tech. 86, 1505-1506. https://doi.org/10.1002/cite.201450573.

Alekhina, M., Erdmann, J., Ebert, A., Stepan, A.M., Sixta, H., 2015a. Physico-chemical properties of fractionated softwood Kraft lignin and its potential use as a bio-based component in blends with polyethylene. J. Mater. Sci. 50, 6395-6406. https://doi. org/10.1007/s10853-015-9192-9.

Alekhina, M., Ershova, O., Ebert, A., Heikkinen, S., Sixta, H., 2015b. Softwood Kraft lignin for value-added applications: fractionation and structural characterization. Ind. Crop. Prod. 66, 220-228. https://doi.org/10.1016/j.indcrop.2014.12.021.
Baker, D.A., Rials, T.G., 2013. Recent advances in low-cost carbon fiber manufacture from lignin. J. Appl. Polym. Sci. 130, 713-728. https://doi.org/10.1002/app.39273.

Baker, D.A., Gallego, N.C., Baker, F.S., 2012. On the characterization and spinning of an organic-purified lignin toward the manufacture of low-cost carbon fiber. J. Appl. Polym. Sci. 124, 227-234. https://doi.org/10.1002/app.33596.

Beauchet, R., Monteil-Rivera, F., Lavoie, J.M., 2012. Conversion of lignin to aromaticbased chemicals (L-chems) and biofuels (L-fuels). Bioresour. Technol. 121, 328-334. https://doi.org/10.1016/j.biortech.2012.06.061.

Bengtsson, A., Bengtsson, J., Olsson, C., Sedin, M., Jedvert, K., Theliander, H., Sjöholm, E., 2018. Improved yield of carbon fibres from cellulose and Kraft lignin. Holzforschung 72, 1007-1016. https://doi.org/10.1515/hf-2018-0028.

Björk, M., Rinne, J., Nikunen, K., Kotilainen, A., Korhonen, V., Wallmo, H., Karlsson, H., 2015. Successful start-up of lignin extraction at Stora Enso Sunila Mill. In: NWBC 2015. The 6th Nordic Wood Biorefinery Conference: Helsinki, Finland, 20-22 October, 2015. VTT, Espoo (Finlande), pp. 185-192.

Chakar, F.S., Ragauskas, A.J., 2004. Review of current and future softwood Kraft lignin process chemistry. Ind. Crop. Prod. 20, 131-141. https://doi.org/10.1016/j.indcrop. 2004.04.016.

Culebras, M., Sanchis, M.J., Beaucamp, A., Carsí, M., Kandola, B.K., Horrocks, A.R., Panzetti, G., Birkinshaw, C., Collins, M.N., 2018. Understanding the thermal and dielectric response of organosolv and modified Kraft lignin as a carbon fibre precursor. Green Chem. 20, 4461-4472. https://doi.org/10.1039/C8GC01577E.

Energy Information Administration, 2017. Spot price natural gas. https://www.eia.gov/ naturalgas/weekly/, Accessed date: 29 August 2017

Erdocia, X., Prado, R., Corcuera, M.Á., Labidi, J., 2014. Base catalyzed depolymerization of lignin: Influence of organosolv lignin nature. Biomass Bioenergy 66, 379-386. https://doi.org/10.1016/j.biombioe.2014.03.021.

FAO - Food and Agriculture Organization of the United Nations, 2015. Pulp and Paper Capacities 2015-2020. (Rome).

Frank, E., Steudle, L.M., Ingildeev, D., Sporl, J.M., Buchmeiser, M.R., 2014. Carbon fibers: precursor systems, processing, structure, and properties. Angew. Chem. Int. Ed. Engl. 53, 5262-5298. https://doi.org/10.1002/anie.201306129.

Gargulak, J.D., Lebo, S.E., McNally, T.J., 2000. Lignin. In: John Wiley \& Sons Inc (Ed.), Kirk-Othmer Encyclopedia of Chemical Technology. John Wiley \& Sons, Inc, Hoboken, NJ, USA.

Gellerstedt, G., Tomani, P., Axegård, P., Backlund, B., 2013. Chapter 8. Lignin recovery and lignin-based products. In: Christopher, L. (Ed.), Integrated Forest Biorefineries. Challenges and Opportunities. Royal Society of Chemistry, Cambridge, pp. 180-210.

Gierer, J., 1980. Chemical aspects of Kraft pulping. Wood Sci.Technol. 14, 241-266. https://doi.org/10.1007/BF00383453.

Hansen, C.M., 2007. Hansen Solubility Parameters: A user's Handbook, 2nd ed. Crc Press, Boca Raton (519 pp).

Huang, X., Korányi, T.I., Boot, M.D., Hensen, Emiel J.M., 2015. Ethanol as capping agent and formaldehyde scavenger for efficient depolymerization of lignin to aromatics. Green Chem. https://doi.org/10.1039/C5GC01120E.

alibaba.com Price for sodium hydroxide. https://www.alibaba.com/showroom/price-forsodium-hydroxide.html, Accessed date: 29 August 2017.

alibaba.com Price for sulfuric acid: 220 \$/t. https://www.alibaba.com/trade/search? $\mathrm{fsb}=\mathrm{y} \& I$ IndexArea $=$ product_en $\&$ CatId $=\&$ SearchText $=\mathrm{H} 2 \mathrm{SO} 4$, Accessed date: 29 August 2017.

Johnson, M.A., Hart, P.W., 2016. Integrating a biorefinery into an operating Kraft mill. Bioresources 11. https://doi.org/10.15376/biores.11.4.Johnson.

Kadla, J., Kubo, S., Venditti, R., Gilbert, R., Compere, A., Griffith, W., 2002. Lignin-based carbon fibers for composite fiber applications. Carbon 40, 2913-2920. https://doi. org/10.1016/S0008-6223(02)00248-8.

Katahira, R., Mittal, A., McKinney, K., Chen, X., Tucker, M.P., Johnson, D.K., Beckham, G.T., 2016. Base-catalyzed depolymerization of biorefinery lignins. ACS Sustain. Chem. Eng. https://doi.org/10.1021/acssuschemeng.5b01451.

Kouisni, L., Holt-Hindle, P., Maki, K., Michael, Paleologou, 2012. The LignoForce System $^{\mathrm{TM}}$ : a new process for the production of high-quality lignin from black liquor. J. Sci. Technol. For. Prod. Process. 2, 6-10.

Lake, M.A., Blackburn, J.C., 2014. SLRP ${ }^{\mathrm{TM}}$ - an innovative lignin-recovery technology. Cellul. Chem. Technol. 48, 799-804.

Li, T., Remón, J., Shuttleworth, P.S., Jiang, Z., Fan, J., Clark, J.H., Budarin, V.L., 2017. Controllable production of liquid and solid biofuels by doping-free, microwave-assisted, pressurised pyrolysis of hemicellulose. Energy Convers. Manag. 144, 104-113. https://doi.org/10.1016/j.enconman.2017.04.055. 
Mahmood, N., Yuan, Z.S., Schmidt, J., Xu, C.B., 2013. Production of polyols via direct hydrolysis of Kraft lignin: effect of process parameters. Bioresour. Technol. 139, 13-20. https://doi.org/10.1016/j.biortech.2013.03.199.

Mainka, H., Hilfert, L., Busse, S., Edelmann, F., Haak, E., Herrmann, A.S., 2015. Characterization of the major reactions during conversion of lignin to carbon fiber. J. Mater. Res. Technol. 4, 377-391. https://doi.org/10.1016/j.jmrt.2015.04.005.

Methanex. Methanol pricing: $250 € /$ t. https://www.methanex.com/our-business/pricing. Accessed 29 August 2017.

Miller, J.E., Evans, L.R., Mudd, J.E., Brown, K.A., 2002. Batch Microreactor Studies of Lignin Depolymerization by Bases: 2. Aqueous Solvents. Sandia National Laboratories.

Nagy, M., Kosa, M., Theliander, H., Ragauskas, A.J., 2010. Characterization of CO2 precipitated Kraft lignin to promote its utilization. Green Chem. 12, 31-34. https:// doi.org/10.1039/B913602a.

Otromke, M., Shuttleworth, P.S., Sauer, J., White, R.J., 2018. Hydrothermal base catalysed treatment of Kraft lignin for the preparation of a sustainable carbon fibre precursor. Bioresour. Technol. Rep. https://doi.org/10.1016/j.biteb.2018.11.001.

Paul, R., Dai, X., Hausner, A., Naskar, A.K., Gallego, N.C., 2015. Treatment of lignin precursors to improve their suitability for carbon fibers: a literature review. In: Carbon Fibers and their Composites, (Oak Ridge, TN, USA. 16.-17.04.2015).

Pescia, D., Reidl, C., 2014. Comparing Electricity Prices for Industry. Agora Energiewende.

Ragnar, M., Henriksson, G., Lindström, M.E., Wimby, M., Blechschmidt, J., Heinemann,
S., 1999-2014. Pulp. In: Ullmann's Encyclopedia of Industrial Chemistry. Wiley Interscience, Hoboken, NJ.

Rinaldi, R., Jastrzebski, R., Clough, M.T., Ralph, J., Kennema, M., Bruijnincx, Pieter C.A., Weckhuysen, B.M., 2016. Paving the way for lignin valorisation: recent advances in bioengineering, biorefining and catalysis. Angew. Chem. Int. Ed. Engl. 55, 8164-8215. https://doi.org/10.1002/anie.201510351.

Roberts, V.M., Stein, V., Reiner, T., Lemonidou, A., Li, X., Lercher, J.A., 2011. Towards quantitative catalytic lignin depolymerization. Chem. Eur. J. 17, 5939-5948. https:// doi.org/10.1002/chem.201002438.

Schmiedl, D., Endisch, S., Rückert, D., Reinhardt, S., Unkelbach, G., Schweppe, R., 2012 Base catalyzed degradation of lignin for the generation of oxy-aromatic compounds possibilities and challenges. Erdöl Erdgas Kohle 128, 357-363.

Sudo, K., Shimizu, K., 1992. A new carbon fiber from lignin. J. Appl. Polym. Sci. 44, 127-134. https://doi.org/10.1002/app.1992.070440113.

Toledano, A., Serrano, L., Labidi, J., 2014. Improving base catalyzed lignin depolymerization by avoiding lignin repolymerization. Fuel 116, 617-624. https://doi.org/10 1016/j.fuel.2013.08.071

Tomani, P., 2010. The lignoboost process. Cellul. Chem. Technol. 44, 53-58.

Tran, H., Vakkilainnen, E.K., 2007. The Kraft Chemical Recovery Process. TAPPI - The American Pulp and Paper Industry. (Accessed 1 August 2015)

Wittkowski, R., Ruther, J., Drinda, H., Rafiei-Taghanaki, F., 1992. Formation of Smoke Flavor Compounds by Thermal Lignin Degradation. vol. 490. pp. 232-243. https:// doi.org/10.1021/bk-1992-0490.ch018. 
Karlsruher Institut für Technologie

\section{Repository KITopen}

Dies ist ein Postprint/begutachtetes Manuskript.

Empfohlene Zitierung:

Otromke, M.; Shuttleworth, P. S.; Sauer, J.; White, R. J.

Hydrothermal base catalysed treatment of Kraft lignin - time dependent analysis and a techno-economic evaluation for carbon fibre applications.

2019. Bioresource technology reports, 6 .

doi: $10.5445 / / R / 1000092667$

Zitierung der Originalveröffentlichung:

Otromke, M.; Shuttleworth, P. S.; Sauer, J.; White, R. J.

Hydrothermal base catalysed treatment of Kraft lignin - time dependent analysis and a techno-economic evaluation for carbon fibre applications.

2019. Bioresource technology reports, 6, 241-250.

doi:10.1016/..biteb.2019.03.008 